\title{
7. The Post-Courier and media advocacy: A new era in Papua New Guinean journalism?
}

\section{AB SIRA}

The Papua New Guinea media is often described as 'free' and 'vibrant' compared to other media in developing countries in the region. The style of journalism and the news values are based on the Western model familiar in developed countries, where objectivity is one of the conventions of journalism practice. This is a result of influence on the PNG media by Western news values through a history of ownership of the local media and training in journalism provided at the workplace and at journalism schools in PNG. However, the coverage of two major national issues by PNG's national daily Post-Courier has signalled a shift in reportage style in PNG to one of advocacy journalism. The two major issues are the National Superannuation Fund of Papua New Guinea (NASFUND) corruption crisis and an anti-gun campaign. Although at present both issues have dropped out of the media, they have yet to reach satisfactory conclusions. The prosecution of people involved in the NASFUND mismanagement is pending while the anti-gun campaign report has been tabled in Parliament, but nothing has been heard about it since. This article examines the role of the Post-Courier and its coverage of the two issues and why it chose to use advocacy style journalism for its coverage. The coverage has drawn criticism from sectors of society and other journalists. The article also examines the views of journalists in Papua New Guinea about the Post-Courier's coverage and advocacy journalism.

PATRICK MATBOB

Divine Word University, Madang, PNG 


\title{
Introduction
}

T N 2001 the Post-Courier, Papua New Guinea's leading daily newspaper, reported a case of major financial mismanagement within the National Superannuation Fund of Papua New Guinea, a savings fund for some 60,000 workers in the country. Contributors lost 15 percent of their savings in a subsequent write-down of the fund value. The Post-Courier was at the forefront of a vigorous campaign to get those responsible to answer for what had happened (O. Philemon, interview, 19 July 2005)

\begin{abstract}
Three years later, the newspaper launched an anti-gun campaign in response to a perceived and alarming build up of illegal arms in the country. The anti-gun campaign involved a committee that sought the views of the people about the problem and submitted a report to Parliament (Philemon interview).
\end{abstract}

The way the newspaper had covered these two issues raised questions about the role of journalists and the media in Papua New Guinea. In both cases, the paper had played an advocacy role by taking a stance and campaigning openly with the view to achieving a result.

This article studies the coverage of the two issues between 2000 and 2005 and finds that the Post-Courier did play an advocacy role. However, the journalists interviewed are not able to agree on whether the Post-Courier's advocacy role was justified and was the right thing to do. Despite a commission of inquiry and the newspaper's extensive coverage from 2001 to 2005, only one person was successfully prosecuted in the case (NPF crook back for special sentence, 2005). The case was quietly concluded early in 2007 when a magistrate's court discharged former NASFUND chairman Jimmy Maladina on charges against him due to insufficient evidence (Krau, 2007). The anti-gun campaign report however, remains outstanding and the government has taken no action so far.

\section{Brief background of the cases}

NASFUND crisis

NASFUND (National Superannuation Fund) is one of Papua New Guinea's largest superannuation funds that manage the savings of all private sector workers in the country. Until the crisis, the fund was known as the National Provident Fund. By law, all organisations who employ more than 20 
employees must be members of the fund if they are not contributing to other legally recognised funds. The fund was set up by the state because PNG does not provide social security to support the unemployed and the retired. Because of the legal requirement, all major private media organisations, including the Post-Courier, were also members of the fund. Since the establishment of the fund in the early 1980s, it had been performing well up until the end of the 1990s. Poor investment decisions and political interference in the management of the fund led to the loss of millions of kina belonging to PNG workers. As a result, the value of the fund had to be rewritten thus all investors were to lose 50 percent of their savings. Following a public outcry, the government intervened and pumped in some funds cutting the losses to 15 percent (Nasfund Annual Report 2000).

\section{Anti-gun campaign}

The proliferation of illegal guns, both factory and home made, within the communities in Papua New Guinea has been a major problem for some years. While the guns in urban centres have been used mainly to commit crimes, the majority of the weapons in rural areas are used in tribal conflicts. The majority of the factory-made weapons are believed to have come from the armouries of the disciplined forces, army and police, while a few have been smuggled in. Politicians and civil servants are responsible for financing and facilitating gun running and many people, including some prominent Papua New Guineans, have been killed by gun-wielding criminals while hundreds more are traumatised by the experience (Alpers, 2005). Post-Courier editor-in-chief Oseah Philemon was a key figure in the anti-gun campaign advocated by his newspaper after being held up twice at gunpoint. He also had to deal with several cases of gun-related crimes against his newspaper operations (Philemon interview).

\section{Advocacy journalism and other forms}

Media advocacy, or advocacy journalism, is a form of journalism that supports a specific point of view on one or more issues. Often advocacy journalism might focus on stories concerning corporate business practices, government policies, political corruption and social issues and is arguably done in the public interest and is critical of the notion of objectivity (Wikipedia). While traditionally advocacy is restricted to editorial and opinion pages and sections of the media, it is practised by a broad range of alternative media and special interest publications. Janowitz as quoted by 
McCarthy in the Australian Journalism Review (2000, p. 89) defines advocacy journalism as:

The task of the journalist ... to represent the viewpoints and interests of competing groups, especially those of excluded and underprivileged groups ... the journalist must participate in the advocacy process ... he must point out the consequences of the contemporary power balance.

In the developing world advocacy journalism is described as abiding by the values of journalism yet, is undertaken for a cause often involving human rights and social change (www.ghanaweb.com). There are also other forms of journalism devoted to similar values such as public, civic and community journalism.

What is central to these forms of journalism is that they are critical of the notion of objectivity (Robie, 1995, pp. 5-15). Objectivity as practised in journalism requires journalists to remain detached from the stories they write and are not supposed to add their opinions, claims and arguments or make judgements but present facts as they are. They must balance stories and seek views from credible sources or experts. According to Hackett and Zhao (1998), the notion of objectivity in journalism can be traced back as far as the 1880s within the labour press. However, Schudson (1978) says the rules and procedures to ensure objectivity in news developed during World War I when journalists experienced the propaganda and public relations associated with the war effort. Journalists realised that the world they reported on was constructed for them by the government's public relation and propaganda men and therefore could not trust the 'simple facts' anymore. So they were forced to develop an allegiance to rules and procedures for a world where even facts were in question (1978).

In recent times, some media practitioners and scholars such as Merritt, Rosen, Carey et al, argue that objectivity is impossible because everyone has his or her own personal views or biases. They contend however, that these views can be presented in a fair and balanced way. This is evident, for instance with foreign correspondents, who Schudson says practice 'interpretive journalism' because of the increasing complexity of the world and because readers want more background and interpretation.

One form of journalism that is being widely debated today is the idea of public journalism which evolved in the US and has similarities to advocacy 
journalism. According to Rosen, public journalism is based on the 1920s writings of Walter Lippmann and John Dewey who debated what should be the main functions of a newspaper in a democracy. Rosen describes public journalism as:

... an approach to the daily business of the craft that calls on journalists
to (1) address people as citizens, potential participants in public affairs,
rather than victims or spectators; (2) help the political community act
upon, rather than just learn about, its problems; (3) improve the climate
of public discussion, rather than simply watch it deteriorate; and (4)
help make public life go well, so that it earns its claim on our attention
$(1999$, p. 22$)$.

In Papua New Guinea, there are persisting development problems that are likely to compel journalists and media organisations to take up advocacy roles (Robie, 1995). The chronic social, political and economic problems fuelled by widespread corruption and misuse of resources, have persuaded the PNG media to join other public and private organisations to work towards restoring good governance and stability in the country. The decay in the government's authority, its inability to enforce the rule of law and to investigate major crimes and prosecute offenders has led to loss of confidence within the civil society. This has been highlighted in a report by Australia's Centre for Independent Studies entitled 'PNG On The Brink' (Windybank \& Manning, 2003). The report sparked controversy in PNG mainly among politicians who were unhappy that their efforts to address the problems have not been acknowledged. Post-Courier editor-in-chief Philemon saw the NASFUND crisis and the anti-gun campaign as major public issues and wanted the newspaper to be proactive and get involved in highlighting these issues that were critical to the nation:

I think the newspapers, Post-Courier for instance, must stand up and be counted, taking the lead to get these issues out into the public arena for debate and force the government to take action (Philemon interview).

Philemon also pointed out another reason why his newspaper took up the advocacy role and this had to do with the Fourth Estate or the watchdog role where the media represents or takes the place of the people. Ironical- 
ly, this is because of the PNG media's limited sphere of influence. Firstly, more than 80 percent of the country's population live in rural areas and are generally too poor to afford newspapers, radios and TV sets. Secondly, the country's rugged geographical terrain makes it expensive to distribute papers, while radio and television signals cannot reach every part of the country. Thirdly, more than half of the population are either illiterate or semiliterate and cannot read or understand what is going on in the media. The government radio networks using the short-wave frequencies have the best reach over the mountains and distances: however, a chronic shortage of funding has continuously affected the operation of the stations (Rooney \& Papoutsaki, 2006, p. 13).

This situation places the media and journalists in a position of great responsibility as representatives of the people, the majority of whom are totally unaware of what is going on in the country. Philemon said the newspaper had to be involved 'because we are the voice of the people, if we don't do it this little grassroots people won't do it' (Philemon interview).

\section{The Post-Courier newspaper}

The Post-Courier is Papua New Guinea's oldest and largest selling English-language newspaper with a daily circulation from Monday to Friday of 28, 262 (Audit Bureau of Circulations, 2007). This is out of five million people and all the country's newspapers combined would have a circulation of less than 60,000. Owned by South Pacific Post Ltd, which is a subsidiary of News Ltd, the paper was established in 1969 and is based in Port Moresby city where the newspaper is printed for daily distribution throughout the country (Robie, 1995, pp.21-22). The paper has bureau established in the four main regions of the country. The Post-Courier newspaper is a tabloid size publication produced five days a week and averages 40 pages. Since independence in 1975, the newspaper has nationalised the editor's position, beginning with Luke Sela, then Oseah Philemon and current editor Blaise Nangoi. The events in this study occurred under the management of former editor Philemon, who has now been promoted to editor-in-chief, a new position created recently by the paper

In 2000, after a period of growing speculation about likely problems at NASFUND, the Post-Courier was the first paper to break the news that the fund had been mismanaged and contributors were likely to lose their savings (interview with Abby Yadi, who broke the story, 19 July 2005). It was a story 
that affected the journalists themselves since they were also contributors to the fund. According to Frank Kolma, former editor of The National, the journalists went after those responsible with a vengeance.

As a journalist and an editor I would say the news reports of the time were clearly one-sided in almost all instances (F. Kolma, interview, 19 July 2005).

There was also nationwide fury at the NASFUND managers from 60,000 contributors and their dependents. The Post-Courier was, however, not content with the coverage they were providing and when the former chairman of the fund, Jimmy Maladina, fled to Australia, the newspaper took steps that were unprecedented in PNG journalism to find him and bring him back to answer for the crisis (Philemon interview). The management of the Post-Courier printed T-shirts with slogans saying 'Jimmy Come Back', which were distributed freely to the public to boost this campaign to find Maladina. The editor at the time, Philemon, was relentless in his resolve to ensure that justice was done and kept the story on the media agenda even long after the official inquiry commissioned by the government was over and the report tabled.

While the NASFUND case was continuing, Philemon again set out to start another newspaper campaign-this time against guns in the society. Philemon, who was himself held up twice at gunpoint (interview with author) had become fed up with the lack of action over the growing abundance of guns in the society and decided to do something about it. This time he initiated the campaign, then was involved with the setting up of a committee of which he was a member and travelled around the country holding meetings to gather the views of the people on guns. At the same time, he got his own newspaper journalists and the other PNG media to cover the story on the anti-gun campaign on a regular basis. Journalists in the media industry thought the campaign was a great idea. However some were not comfortable at all with the involvement of the Post-Courier editor in such a direct way (interview with journalists, July 2005).

\section{Methodology}

This study was carried out in two parts. Firstly, a content analysis was done to determine the advocacy role of the Post-Courier in the coverage of the 
NASFUND crisis and the anti-gun campaign. The analysis was to find out the volume of the coverage and the prominence given to the stories which should establish whether or not the Post-Courier played an advocacy role. Secondly, sem-structured indepth interviews were conducted with six print media journalists to find out their views on advocacy journalism and the role of the Post-Courier.

\section{The findings}

\section{Anti-gun campaign}

The Post-Courier ran 189 stories on the anti-gun campaign in the 14-month period that was surveyed, beginning May 2004 up until July 2005, when the summit was held. The majority of the stories ran in the early news pages, 12 stories made the front page, 59 on p. 2,14 on p. 3,25 on p. 4,10 on p. 5,17 on p. 6 and 16 on p. 7. The rest of the stories and features were spread out on the pages further inside the newspaper. The newspaper also commented on the issue in its editorial column 19 times (p. 10) and ran news features on the issue nine times in its inside pages.

The distribution of the stories shows that most stories were given prominence in the news pages, which indicates that the newspaper considered the issue to be important. A total of 189 stories over a period of 14 months works out to about three stories a week for the period and suggests that the issue has been on the newspaper's agenda.

The findings also suggest that Post-Courier has viewed the campaign as important by giving regular space to the stories in the early news pages. The story sizes were standard for Post-Courier ranging from 200 - 400 words.

\section{Stories for and against the campaign}

Table 1 shows the number of stories from the different voices in the community that the Post-Courier ran throughout the campaign and the views they presented. It is clear from the table that 147 out of 189 (77.7 percent) stories run were in support of the campaign - that is for guns to be banned. Only three stories were from a community group and individuals who supported the campaign but said there should not be an outright ban. In fact, the group said that guns were necessary for their defence and suggested that they would only surrender their arms if their politicians led by example and turned in their guns. Two other individuals said people with licences should be allowed to own guns for their own protection while authorities should 


\begin{tabular}{|c|c|c|c|c|}
\hline & $\begin{array}{l}\text { Support } \\
\text { campaign }\end{array}$ & $\begin{array}{l}\text { Support } \\
\text { with } \\
\text { conditions }\end{array}$ & $\begin{array}{l}\text { Against } \\
\text { campaign }\end{array}$ & $\begin{array}{l}\text { Other gun } \\
\text { related } \\
\text { stories }\end{array}$ \\
\hline Politicians & 31 & 1 & 3 & 5 \\
\hline Police & 7 & 0 & 1 & 14 \\
\hline Govt. agencies & 0 & 0 & 0 & 0 \\
\hline Women & 6 & 0 & 0 & 1 \\
\hline Youth & 3 & 0 & 0 & 1 \\
\hline Students & 6 & 0 & 0 & 2 \\
\hline Govt. officers & 8 & 0 & 0 & 1 \\
\hline Post Courier Editorial & 15 & 0 & 0 & 0 \\
\hline Gun committee & 23 & 0 & 0 & 3 \\
\hline Post Courier reporters & 17 & 0 & 1 & 4 \\
\hline Comm leaders & 12 & 0 & 0 & 2 \\
\hline Ombudsman & 1 & 0 & 0 & 0 \\
\hline Church & 2 & 0 & 0 & 0 \\
\hline Professionals & 3 & 1 & 1 & 0 \\
\hline Informants & 2 & 0 & 0 & 0 \\
\hline Army & 1 & 0 & 0 & 0 \\
\hline Prisoners & 1 & 0 & 0 & 0 \\
\hline Community & 7 & 1 & 0 & 0 \\
\hline Teachers & 3 & 0 & 0 & 0 \\
\hline Totals & 147 & 3 & 6 & 33 \\
\hline
\end{tabular}

confiscate illegal guns. Six were against the campaign and argued that guns were necessary for their protection and were against any ban.

A senior police officer was also against the campaign saying that the problem of illegal guns in the community was not as bad as it was made out to be. The other gun related stories (33 or 17 percent) were mainly about the progress of the campaign and other gun issues and did not support or oppose the campaign. Following are examples of the lead sentences in the stories that supported the campaign. 
1. A public gathering at Palmalmal, in East New Britain, called for a total ban on guns and [for] castration of offenders if they [killed] people with guns (Post-Courier Online, 20 May 2005).

2. Leaders of the 1.2 million Roman Catholics in Papua New Guinea want laws changed by Parliament to completely ban private ownership of guns (Post-Courier Online, 26 April 2005).

These examples also show that there were concerns about guns in the community and the people (voices) appreciated the chance to put forward their views in support of the campaign. It was an issue that people had been concerned about for a long time and wanted addressed.

In the areas where there were guns used for tribal fighting, people have spoken frankly to the committee about the need to defend themselves. They also said guns were being supplied to them by their political and community leaders and businessmen. They said they would only hand over their guns if the leaders first handed in their guns. It is apparent here that there must be more people, especially leaders and businessmen, who did not support the campaign. These people have not had their stories told in the campaign. Of course, if these businessmen and leaders have been buying stolen weapons from the disciplined forces and supplying their clansmen and supporters, then they are hardly likely to reveal this to the committee. A sample of a story that was against a ban on guns:

A provincial assembly member and senior public servant have admitted to owning high-powered guns to protect themselves, their families, tribe and property. The provincial politician said he had two guns and a primary school teacher told the national guns control committee in Kundiawa they would not turn in their weapons to the state (Post-Courier Online, 12 April 2005).

These people's lives are constantly threatened by their tribal enemies and they felt that they needed weapons to protect themselves. The Post-Courier has gone out openly on a campaign against guns with a clear intention to get the government to act on it. The proliferation of illegal guns is no doubt a serious problem facing the society. The Post-Courier editor also felt the same way and decided to do something about it by initiating the campaign 
then providing comprehensive coverage of the campaign. From the stories it has published, it has got the desired response from the community to support its campaign.

The NASFUND crisis coverage

A total of 362 NASFUND crisis stories were accessed online and analysed from December 2001-August 2005. Prominence has been given to the stories in terms of their location in the early news pages and through the volume of stories that have been run on the issue. This was done by allocating special feature pages on a daily basis to the crisis stories in the inside pages of the newspaper. Of the 362 stories, 245 appeared on regular news and feature pages, while 117 appeared on supplementary features pages. Of these 117 stories, which ran from November 2002 to April 2003, 85 of them were serialised parts of the NASFUND report that ran for as many days. The other 32 were run in special features over four days. The extended coverage demonstrates the extent to which the newspaper had gone to make the report widely available to the community following complaints by public that they could not get copies of the official report. The 117 stories can still be accessed on the newspaper's website (www.postcourier.com.pg).

Of the 245 stories that were run, 38 made the front page, 51 on page 2, and 44 on page 3. Most of the other stories were situated on pages 4-7 and the rest were spread throughout the inside pages. The Post-Courier published only three editorials on the issue and a reason for the limited newspaper editorial scould be the potentially incriminating nature of the issue and the newspaper had to be careful in expressing an opinion. The case would also have been considered sub judice when the inquiry was on.

\section{Discussion}

The majority of stories (147 out of 189) run by the Post-Courier supported the anti-gun campaign calling for guns to be banned. Most of the other stories (33) were neither for nor against the campaign, while only nine showed some opposition to the campaign. The findings also suggest that the success of the anti-gun campaign is likely to depend on the country's politicians and civil servants. The six voices opposing the ban did so because they said they needed the guns for their own protection and three added that they would hand in their guns if their politicians handed in their guns first. The call for politicians to hand in their weapons confirms the general belief that 
leaders in PNG are responsible for gun running. Alpers in his small arms survey report, entitled Gun Running in Papua New Guinea: From arrows to assault weapons in the Southern Highlands, also finds that gun running in Southern Highlands and parts of PNG are financed and facilitated by politicians and civil servants (Alpers, 2005, p. 24).

Tribal conflicts are a main cause for the proliferation of guns in the community and politicians, civil servants and other leaders are responsible for gun running have to be targeted if the campaign is to be successful.

The findings also show that various sectors of the community, such as the judges, support the idea that guns should be banned in PNG.

The Post-Courier has published more stories supporting the campaign than against it. Was this a true reflection of the community feelings or was the paper told what it wanted to hear? Indeed, one wonders whether only those who were in agreement with the campaign agenda were able to speak out? These questions will remain unanswered. However, there were more voices of community leaders, women, students, etc, in the stories supporting and thus seem to legitimise the campaign. There were few voices against. Fairclough says that news reports 'include mechanisms for ordering voices, subjecting them to social control'.

The mere fact that a plethora of voices is included in media treatments of social and political issues does not entail an absence of control, merely that the question of how voices are woven together, how they are ordered with respect to each other, becomes decisive (1995, p. 84).

The Post-Courier has openly conducted a campaign against guns with the clear intention to get the government to act on gun control. The proliferation of illegal guns is no doubt a serious problem to the society as the Supreme Court judges have reflected. The Post-Courier editor also felt the same way and decided to do something about it by initiating the campaign then providing comprehensive coverage of the campaign. From the stories published, the newspaper has got the desired response from the community to support its campaign.

Again the NASFUND stories have been given importance in the coverage by the prominence given to the stories as well as the large quantity of stories generated on the issue. The decision by the newspaper to publish additional 
features on the inquiry as well as serialising the final NASFUND report over 85 issues of the paper demonstrates the importance given to the issue. The sustained coverage after the Inquiry was over was unusual in that Post-Courier ran detailed versions of stories that had already been covered by reporters during the period of the Inquiry. The newspaper justified its action by saying it wanted the public to have access to the NASFUND report that was tabled in Parliament. Copies of the report were not initially available to the public and Post-Courier put the serialised version it had run on its website where it can still be accessed. Post-Courier editor-in-chief Philemon explained that what they had done was different.

Even though we have covered commissions of inquiries in the past, taking it further than what we have at the conclusion of the commission of inquiry, is something that we have never done before. So it was breaking new ground there (Philemon interview).

Philemon also said that the newspaper's sustained coverage after the inquiry which was dubbed the 'scoreboard', was deliberately done in order to 'show the public that the work of the commission of inquiry has not been a waste, that the police and other authorities have taken action, and it is a very slow process but we believe that the way it is going, justice will be done and seen to be done' (Philemon interview).

It is a deliberate effort on the part of the newspaper not only to expose wrongdoing but also to actively campaign for justice to be done instead of leaving the investigations and prosecution to the appropriate authorities. (Robie, 1999, 2004)

\section{The views from journalists}

Semi-structured in-depth interviews were conducted with six journalists. They were Oseah Philemon, editor-in-chief of the Post-Courier; Veronica Hatutasi, reporter with Wantok; Sam Vulum, former chief subeditor with The National; Frank Kolma, former editor of The National newspaper; Annette Sete, Post-Courier's New Guinea islands region bureau chief; and Abby Yadi, Post-Courier's Mamose region bureau chief.

Anti-gun campaign:

The findings of the interview show that the print media journalists were 
not comfortable with Post-Courier's involvement and coverage of the antigun campaign. Post-Courier's editor-in-chief Philemon, who initiated the campaign, believes that journalists need to be proactive and get involved in highlighting issues that are critical to the nation. His views are supported by Word Publishing's Veronica Hatutasi who says if the media did not initiate the campaign, then no one would have done it — not even the government. She highlighted a case she had been working on involving the assassination of the late Bougainville Premier Theodore Miriung, which has never been resolved despite promises by the government to investigate it. (She had since been warned not to pursue the case for her own safety.) On the other hand, former National editor Frank Kolma cautions newspapers not to go overboard when covering a public debate. A former journalist with The National Sam Vulum, says it is the role of the newspaper only to report issues, and it should not become involved in campaigns. Abby Yadi, a senior Post-Courier journalist also believes in the media maintaining objectivity and remaining neutral while reporting both sides of the story. Annette Sete, Post-Courier bureau chief, believes that the campaign is a community issue and, being a community paper, the Post-Courier has a right to take it up. However, she was still concerned about the newspaper editor getting involved in the campaign.

\section{The NASFUND crisis}

On the NASFUND crisis coverage, Philemon described the Post-Courier's extensive coverage after the inquiry as 'breaking new ground' and said it was meant to 'show the public that the work of the commission of inquiry has not been a waste, that the police and other authorities have taken action and it is a very slow process but we believe that the way it is going, justice will be done' (Philemon interview). The explanation suggests that the newspaper was concerned about the people's lack of confidence in the country's law enforcement and judiciary systems to successfully investigate and prosecute such major cases.

The newspaper has made a deliberate effort not only to expose wrongdoing but to actively campaign for justice instead of leaving the investigations and prosecution to the appropriate authorities.

Philemon described Post-Courier's involvement with NASFUND as 'good journalism' where 'you go after the man until you get him'. Again he is supported by Veronica Hatutasi who praised Post-Courier's involvement, 
saying it 'further gave teeth and push for the issue to be pursued vigorously, landing the matter into the hands of the law and appropriate authorities to deal with'. However, Frank Kolma believes that the media 'departed from fair and impartial journalism' and he singles out the T-shirt campaign as an excellent example. Sam Vulum believes the Post-Courier was not objective and Abby Yadi expresses similar sentiments:

As a journalist, I always maintain that we should not take sides in issues. You know we present all the sides in all the issues and let people decide and not have direct involvement.

Sete sees the media's role as 'invasion of privacy' when it went after Maladina. Yet she says that it is justified because the media has a role to protect the rights and interests of the public and to try and bring Maladina back.

In summary, of the six journalists interviewed, two (Philemon and Hatutasi) supported Post-Courier's advocacy role while Kolma, Vulum and Yadi did not. Annette Sete, while supporting the Post-Courier in general, described the newspaper's hunt for Maladina as 'invasion of privacy' and said there were 'grey areas' in the involvement of Post-Courier's editor in the anti-gun campaign.

\section{Conclusion}

The findings of this study conclude that the Post-Courier played an advocacy role in the coverage of the NASFUND crisis and the anti-gun campaign. It also shows that the newspaper had gone beyond the conventional practices of journalism in PNG while covering both stories. In the NASFUND crisis it printed and distributed t-shirts to drum up publicity and support and in the anti-gun campaign, the editor was personally involved in advocating for the campaign while ensuring that it was well covered by the paper. The study also showed that the journalists were generally uncomfortable with the advocacy role played by the Post-Courier. The study also showed that then Post-Courier editor Oseah Philemon and the management at the time were instrumental in advocating justice in the NASFUND case and a gun-free society in the anti-gun campaign. This is evident from the way the Post-Courier under his editorship has covered the NASFUND and 
the anti-gun campaign stories. With Philemon promoted and a new new general manager at the newspaper it remains to be seen if the paper will take up an advocacy role on other issues.

The NASFUND issue is now effectively over after a magistrate's court dismissed the case against former chairman Jimmy Maladina because of 'insufficient evidence' from the police (Krau, 2007). The Post-Courier's advocacy role had resulted in only one person being charged and jailed (NPF crook back for special sentence, 2005). It seems not to have achieved what editor Philemon had wanted which was for justice to be done and seen to be done (Philemon interview).

The anti-gun campaign was concluded with a report that was tabled in Parliament but little has resulted from it. The gun issue still remains open. It is too early for this study to conclude whether the advocacy role of the Post-Courier is likely to signal a shift in the way journalism is practised in PNG. However, Philemon believes his newspaper is ready to take up the challenge again if needed:

We are a national newspaper, we are the voice, the ears and the eyes of the grassroots people, the people who read our paper, and you got to push some of these issues to the forefront and hope that some positive steps and action will be taken (Philemon interview).

\section{References}

Alpers, P. (2005). Gun running in Papua New Guinea: from arrows to assault weapons in the Southern Highlands. (Retrieved 13 October 2006):

www.smallarmssurvey.org/files/portal/spotlight/country/asia.html\#pap

Altschull, J. H. (1995). Agents of power. New York: Longman.

Audit Bureau of Circulations. (2007, April 10). Post-Courier, p. 2. (Retrieved 10 April 2007): www.postcourier.com.pg/20070410/tuhome.htm

AusAID, 2002, HIV/AIDS in Papua New Guinea. (Retrieved 15 October 2006): www.ausaid.gov.au/country/png/hivaids.cfm.

Bagdikian, B. H. (1999). The media monopoly. In Tumber, H. (Ed.), News: A reader Oxford, New York.

Castrate offenders. (2005, May 20), Post-Courier, p. 6

Christians, C. (1999). The common good as the first principle. In Glasser, T. (Ed.), The Idea of Public Journalism New York: The Guilford Press.

Church wants guns banned. (2005, April 26). Post-Courier, p. 5.

Curan, J. (1997). Rethinking the media as a public sphere. In Dahlgren, P. and Sparks, C. (Eds.), Communication and citizenship. London: Routledge. 
Curan, J.; Smith. A; and Wingate, P. (Eds). (1987). Impact and influences. London: Methuan.

Deacon, D.; Michael, P.; Golding P.; and Murdock, G. (1999). Researching communications London: Arnold.

Dearing, J.; and Rogers, E. (1996). Agenda-setting London: Sage.

Dewey, J. (1991). The public and its problems. Swallow Press.

Dorney, S. (1998). Outwitting repression of the media in PNG. Pacific Journalism Review, 5 (1): pp. 99-106.

Ettema, J.; and Glasser, T. (1998). Custodians of conscience. New York: Colombia University Press.

Evans, J. (n.d.). Publications in Papua New Guinea, PNG Buai.com (Retrieved 18 July 2005). www.pngbuai.com/000general/publishers/papuanewguinea/pngpubs00. html\#otherpublishers

Fairclough, N. (1995). Media discourse London: Edward Arnold.

Fallows, J. (1996). Breaking the news. New York: Random House.

Fowler, R. (1991). Language in the news London: Routledge.

Garnham, N. (1997). The media and the public sphere. In Calhoun, C. (Ed.), Habermas and the public sphere. Cambridge: The MIT Press.

Glasser, T. (Ed.) (1999). The idea of public journalism. New York: The Guilford Press.

Golding, P.; and Elliott, P. (1999). Making the news. In Tumber, H. (Ed.), News: A reader. New York: Oxford.

Habermas, J. (1999). The structural transformation of the public sphere. Cambridge: Polity Press.

Hackett, R.; and Zhao, Y. (1998). Sustaining democracy? Toronto: Garamond Press.

Hartley, J. (1982). Understanding news London: Routledge.

Krau, D. (2007, February 15), Maladina discharged, Post-Courier, p. 5.

Kitzinger, J. (Ed.) (1997). The circuit of mass communication. London: Sage.

Leaders admit illegal arms. (2005, April 12). Post-Courier, p. 4.

Leonard, T. (1999). Making readers into citizens - the old-fashioned way. In Glasser. T. (Ed.), The idea of public journalism. New York: The Guildford Press.

McCarthy, N. (2000). Alf Rattigan and the journalists: advocacy journalism and agenda setting in the Australian tariff debate 1963-1971. (Retrieved 15 October 2006): http://eprint.uq.edu.au/archive/00000877/01/nm_ajr_22_00.pdf

McCombs, M. E. and Shaw, D. L. (1999). The agenda-setting function of mass media. In Tumber, H. (Ed.), News: A reader. New York: Oxford.

Melkote, S. and Steeves, L. (2001). Communication for development in the third world. New Delhi: Sage.

Merritt, D. (1998). Public journalism and public life. New Jersey: Lawrence Erlbaum Associates.

NASFUND, Annual Report 2002 (Retrieved 15 October 2006):

nasfund.com.pg

NPF crook back for special sentence. (2005, June 23), Post-Courier, p. 4. 
NPF final report, 2002-3, Post-Courier Online. (Retrieved 18 July 2005): www.postcourier.com.pg

Pauly, J. (1999). Journalism and the sociology of public life. In Glasser, T. (Ed.), The idea of public journalism. New York: The Guildford Press.

Peters, J. (1999). Public journalism and democratic theory: four challenges. In Glasser, T. (Ed.), The idea of public journalism. New York: The Guildford Press.

Public Agenda, Media Studies, Why advocacy journalism? (Retrieved 2 October 2006): www.ghanaweb.com/public_agenda/issue.php?PUBLISHED=2005-12$12 \& \mathrm{CAT}=7$

Robie, D. (Ed.) (1995). Nius bilong Pasifik: mass media in the Pacific. Port Moresby: University of PNG Press.

Robie, D. (1999). Pacific newsrooms and the campus: some comparisons between Fiji and Papua New Guinea, Australian Studies in Journalism 8: pp. 176-196.

Robie, D. (2004). Pacific newsroom profiles: media literacy and education in Fiji, Papua New Guinea. Paper presented at the Journalism Education Association (JEA) conference, Suva, Fiji, 5-9 December 2004.

Rosen, J. (1999). What are journalists for? New Haven: Yale University Press.

Schudson, M. (1978). Discovering the news. BasicBooks.

Solomon, A. (1995). Hidden obstacles to the real story. In Robie, D. (Ed.) Nius bilong pasifik: mass media in the Pacific (pp. 119-126). Port Moresby: University of PNG Press.

Standish, B. (2002). Papua New Guinea politics: attempting to engineer the future. Development Bulletin, 60: pp. 28-32.

Wimmer, R. and Dominick, J. (2003). Mass Media Research, Wadsworth, US.

Wikipedia, 2006, Advocacy journalism (Retrieved 10 April 2007): http://en.wikipedia.org/wiki/Advocacy_journalism.

Windybank, S. and Manning, M. (2003). Papua New Guinea on the brink, The Centre for Independent Studies. 30: pp. 1-16.

Patrick Matbob is a lecturer in the Communication Arts Department at Divine Word University, Madang, Papua New Guinea. He was formerly a journalist with the Post-Courier and the Times of Papua New Guinea from 1985-2000. An earlier version of this article was presented at the Second Joint Journalism Education Association (JEA)/Journalism Education Association of New Zealand (JEANZ) conference at Auckland, New Zealand, 4-7 December 2006. pmatbob@dwu.ac.pg 
Copyright of Pacific Journalism Review is the property of Auckland University of Technology and its content may not be copied or emailed to multiple sites or posted to a listserv without the copyright holder's express written permission. However, users may print, download, or email articles for individual use. http://www.aut.ac.nz/depts/commstud/journ/pjrsubs.shtml 